\title{
Expression of concern: Which specific modes of exercise training are most effective for treating low back pain? Network meta-analysis
}

Owen PJ, Miller CT, Mundell NL, et al. Which specific modes of exercise training are most effective for treating low back pain? Network meta-analysis. Br J Sports Med Published Online First: 30 October 2019. Doi. 10.1136/bjsports-2019-100886

The manuscript 'Which specific modes of exercise training are most effective for treating low back pain? Network meta-analysis' was published in British Journal of Sports Medicine.

This is in response to the discussion article by Maher and colleagues with concerns that the article may indicate the cardinal limitation of network meta-analysis and the impact of appearing not to address this limitation.

The journal has asked the authors to respond. In the meantime, we are releasing this statement of concern to alert readers and policymakers to uncertainty about the weight and significance of the findings reported herein.

\section{() \\ OPEN ACCESS}

Open access This is an open access article distributed in accordance with the Creative Commons Attribution Non Commercial (CC BY-NC 4.0) license, which permits others to distribute, remix, adapt, build upon this work noncommercially, and license their derivative works on different terms, provided the original work is properly cited, appropriate credit is given, any changes made indicated, and the use is non-commercial. See: http://creativecommons.org/licenses/by-nc/ 4.0\%.

(C) Author(s) (or their employer(s)) 2020. Re-use permitted under CC BY-NC. No commercial re-use. See rights and permissions. Published by BMJ.

Br J Sports Med 2020;0:1. doi:10.1136/bjsports-2019-100886eoc1

D) Check for updates 